\title{
Poverty Review in Novel Padang Bulan Karya Andrea Hirata
}

\author{
Oktavianus Saroyan Joat \\ Udayana University; Postgraduate Faculty of Cultural Sciences \\ Jl. Nias Island No 13, Dauh Puri Klod, West Denpasar \\ Telephone (0361) 22412, e-mail: roysastra04@yahoo.com
}

\begin{abstract}
This research describes the poverty problem described in the Padang Bulan novel by Andrea Hinata through the social life of the Belitung Malay community. This research aims to reveal various forms of the social life of the community and deconstruct the discourse hidden behind the social life of the society that the author describes according to the social life of the Belitung Malay community. According to deconstruction theory, power and knowledge relations used in this research to analyze data through the sociological approach of literature. This research uses qualitative methods, especially literature studies that are commonly applied in the study of literary texts. This study found that poverty described by the author towards Belitung Malay society was very clear showing the social reality experienced by most Indonesian people and storing various relations of power and knowledge through various discourses played by the capitalists to benefit without regard to the working class, namely society.
\end{abstract}

Keywords: poverty, novels, society, social

\section{INTRODUCTION}

Poverty is a very basic problem and becomes a phenomenon or part of a country's development. Conceptually, poverty involves conditions where a person is unable to meet his needs. Poverty is also defined as a condition in which a person is unable to maintain himself under the standard of life of the group and is also unable to utilize his mental or physical energy in the group (Soekanto, 1982: 320).

Literature is a social institution that uses the medium of language (Wellek and Warren, 2014: 98). Literature is associated with certain situations, or with certain political, economic, and social systems. The study was conducted to describe the influence of society on literature and its position in society. In this case, the author must be sensitive to the social situation and the fate of the proletariat (Wellek and Warren, 2014: 99).

Through novels, the author tries to give a picture of the reality of life through stories. The novel contains values that are beneficial for the life of low or middle society. As stated Ratna (2007: 335) among the main groups of literary works, namely poetry, prose, and drama groups, especially novels which are considered the most dominant in presenting social elements.

Literary work, in this case, stands as the object of study to be examined. Various social problems about poverty are clearly illustrated in literary works. The Padang Bulan novel by Andrea Hirata clearly shows the social life of Indonesian people that is still categorized as the poor, as evidenced in various novel excerpts described by the author in various situations faced by the characters. The Padang Bulan novel was chosen in this study because it is very interesting to study it under the life of certain social classes in the present with various discourses hidden by the capitalists. The advantages of this month's Padang novel are lifted from true stories so that their interpretation of the life of social class is very clear.

In Indonesia, it seems that the presence of class or rather social strata (elite-people) often intersects. An intersection that extends to the issue of power also often attracts the attention of writers. That is why literary works can be seen as a reflection of social life and power. The poverty analysis in the novel also aims to deconstruct the hidden discourse behind the social life of the community described by the author with the social life of the Belitung Malay people. The control of the capitalists over the workers, the use of labor which is incompatible with the wages received by the proletariat. Deconstructing means taking, "changing" to find and show the assumptions behind a text. The purpose of deconstruction is not only to reverse the arrangement or order of the binary pair but to show how one cannot be separated from the other (Barker, 2014: 6970).

The theory of power and knowledge relations proposed by Michael Foucault also plays an important role in analyzing various quotations 
contained in the novel. Power is a complex strategy in a society with certain equipment, maneuvers, techniques, and mechanisms. Generally, it must be recognized that power is more than possessed. Power is not a privilege obtained or maintained by the dominant class, but a result of its overall strategic position (Haryatmoko, 2016: 15). The existence of hidden discourse in the literary work can be seen from the contents of the Padang Bulan novel which illustrates the power relations behind the presence of the proletariat as the working class. Between the government and employers who work behind the presence of the knowledge and power displayed.

The sociology of literature approach is also used by researchers to study the novel because there is a fundamental connection between the social life of figures and literary works. Literary sociology by itself studies the nature of relationships between members of society, literature and knows the reasons for the creation of these relationships with all its effects (Soekanto in Wahyunintyas, 2011: 21). Although sociology and literature have certain differences but actually can explain the meaning of literary texts. This can be understood because of the sociology of the object of his study of humans and literature too.

Endraswara (2013: 77) outlines that the sociology of literature is a branch of reflective literary research. This research is much in demand by researchers who want to see literature as a mirror of people's lives. Therefore, the basic assumption of literary sociology research is the birth of literature not in a social vacuum. Social life will trigger the birth of literary works. Successful or successful literary works that can reflect his day. Damono (in Faruk 2010: 4) argues that there are at least three different types of approaches in literary sociology, namely: a) Author's sociology, namely sociology that concerns social status, social ideology and others that involve authors as producers of literary works. b) Sociology of literary works, namely sociology that put the literary work itself, including the objectives and other matters relating to social issues. c) The sociology of the reader, that is, the sociology that puts the reader in and the social influence of literary works.

The cause of poverty can be known from several factors. Suharto (2009: 31) mentions that poverty is associated with many causes including individual causes, low education levels, and unemployment. The cause of poverty described in the novel is made as to the main problem that can trigger the emergence of various views and benchmarks about what poverty is. While the characteristics of poverty by the picture presented by the novel and the main causes of poverty include slums, despicable, tattered, and dirty. While the purpose of this research is to answer various issues concerning poverty in the novel Padang Bulan by Andrea Hirata. The objectives to be achieved by researchers in this study;
Describe problems, causes, and provide solutions related to poverty in the novel Padang Bulan by Andrea Hirata.

\section{METHOD}

This research uses qualitative methods, especially library research (literature study) which is commonly applied in the study of literary texts. Sources of data in this study consisted of primary data and secondary data. Researchers use a literature study from George (2008: 16) that can turn imagination into an insight. These steps include: (1) choosing a topic, (2) turning it into an image, (3) clarifying research questions, (4) developing a research strategy, (5) finding references from various data, (6) identifying sources data sources, (7) assessing / matching data sources based on research questions, (8) exploring insights based on reflection, and (9) compiling thesis statements based on these insights. Primary data in this study are novels titled Padang Bulan by Andrea Hirata, while secondary data include scientific papers and reference books. The type of data collected by listening and note technique, the researcher reads the novel several times then examines and rewrites the quotations that are very closely related to the theme (poverty) that will be examined and then begins to analyze according to the objectives to be achieved using a sociological approach to literature.

\section{RESULTS AND DISCUSSION}

The results of the study are presented based on data that has been found. Each data is a series of depictions of poverty in the novel Padang Bulan by Andrea Hirata. Research findings are presented to find out what data is contained in the novel. To clarify the findings of the findings, the research can be classified as follows (1) depictions of poverty, namely:

(a) slums, (b) despicable, (c) tattered, and (d) dirty, (2) causes of poverty, namely: ( a) individual causes, (b) low levels of education, and (c) unemployment. (3) poverty solutions, namely: (a) education, (b) providing land for the people, (c) meeting import needs, (d) creating jobs.

\section{Description of Poverty}

\section{a. Grumpy}

Circumstances that contain obsolescence characteristics, many are aimed at land use conditions or zones or areas that have been difficult to repair anymore, so those that have been well dismantled, but can also be addressed to conditions that are still physically good enough are not anything, but it's not again meet various eligibility standards. 
Because this child will be four, whereas they only have a rickety bicycle (Hirata, 2011, p. 6).

The situation of the bicycles which makes it impossible to piggyback the children off to the market, in this case, Syalimah just cried and silently lamented her husband. Their family life is increasingly difficult to overcome.

\section{b. Despicable}

Perhaps because Malays like us never celebrate birthdays, and never care about the day of birth, on the contrary to Chinese people it is very important (Hirata, 2011: 61).

The Belitung Malay people as the native population and the majority are followed by ethnic Chinese, have a different culture. In the quote above, it happened in the Enong school environment, which discusses birthday traditions. The tradition is known to be often practiced by Chinese people. Malay people who are poor are considered unfit for celebrating birthdays.

Then, he reminded seriously that the cake was not suitable for the stomachs of kampong people like us (Hirata, 2011: 64).

Social depictions of poverty experienced by the Belitung Malay children about birthday celebrations, lead them to habits that they have never done as something that is prohibited. It seems that there is the social isolation that the birthday celebration is only intended for the children of the rich who live in the elite complex of the building owned by the tin airline officials. While tin miners are not fit to celebrate birthdays (Faruk, 2010: 49).

\section{c. Tattered}

Poverty with the definition above is very easy to find in social life. Beggars, street children, low-paid company workers, garbage scavengers, farmers or rice farmers with very small wages, street vendors, scattered before our eyes. Slums, bridges, and cardboard houses are not foreign sights in urban areas. Land-lined houses, thatched houses, or housed with pets are also not unusual phenomena. Eating tiwul, eating agate rice, or eating the leftovers from trash cans is also not a proclamation that gives birth to a sense of concern and moves everyone's concern (Ratna, 2007: 335).

"That night, Enong slept on a cardboard box on the storefront, on Jalan Sriwijaya, near the DPRD office. That night, Enong began vagrancy" (Hirata, 2011: 42).

While Enong was looking for work in the city, Syalimah ran out of rice and was forced to borrow from another family. In some of the quotations above, the Zamzami family includes people who have the will to get out of the poverty line. Although Enong is known to have no diploma and expertise, he still tries to find work so he can give Shalimah money to buy rice. Enong's efforts to find work in Tanjong Pandan and being apart from her mother and sister forced Enong to become independent. One night when he did not get a job he slept in the storefront, because he did not have relatives in Tanjong Pandan.

Returning from Tanjong Pandan, Enong found the situation at his home very heartbreaking. The most he feared happened, his mother had to get his younger siblings out of school because they could not afford dues (Hirata, 2011: 58).

The novel excerpt above illustrates a hidden discourse namely the powerlessness of the government to overcome the problems faced by the children of the nation. The writer indirectly wants to convey a message to the government on what is experienced by small communities. Deconstruction means taking, changing or finding assumptions in a text (Barker, 2014: 69). Here, the role is to expose the discourse behind what the Enong family is facing. Enong's decision to leave school aside from the increasingly expensive tuition fees, he also had to send his three siblings to school. The desire to work does not break his enthusiasm to study again and take courses. Enong's inexperience made her be rejected by many factory owners. Enong also doesn't have an elementary school certificate because she left school before she took the exam. The case experienced by Enong is a picture of poverty due to a lack of education services. Higher education costs forced Syalimah to expel her children from school. The decision was taken because there was no cost to send their children to school while Enong never found a job.

Dredgers were once the rhythmic beaters of our lives. It is an important part of our culture. Because all the workforce men work alternately for 24 hours. I will never forget, every two o'clock in the morning, the dredger truck carrier picks up my father. I heard a horn. Father left the house in the early morning while carrying a basket of food from Mother (Hirata, 2011: 22).

Government attention to labor exploitation is a major problem that must be resolved to reduce poverty. Labor exploitation can be in the form of payment of low wages to workers compared to the duration of work. Factors causing poverty associated with labor are an unfair division of production. The pursuit of maximum profits is the company's priority so that production costs are minimized. Here the capitalists see how they employ workers in Indonesia without regard to the wages and welfare of the people.

d. Filthy

Filthy means the conditions that are still dirty for a few weeks they do not use water for daily needs so that their body condition is still dirty. 
The tin miners are called raw coolies, which means coolies are the most coolie. Position under them only load the horse and plow cattle (Hirata, 2011: 60).

Traditional tin miners always retire early like the director of BUMN. Not because they have spent most of their money, are tired of meetings, or are being forced by the government, but because their bodies are worn out before they get old. Arthritis, an outbreak of elephant disease, a strange skin disease due to the mud virus, a lung that is destroyed because it is always withstanding the cold by constantly smoking, and because of the poor, purchased cigarettes are very cheap cigarettes that are abysmally originated, then seized currents, overwritten by landslides, smoked by live sand, struck by lightning, wrapped in snakes or swallowed by crocodiles, are tragic forms of the end of their short and regal careers. Here we see that there is no responsibility in the form of insurance to workers and benefits that should be the obligation of SOEs to fulfill responsibilities to the working class.

When he got home, he took his hoe and dulang's father first, then immediately returned to the lake. He rolled up his sleeves, dropped off his condolence and began digging in the mud. He continued to dig and dig. He blinked as a man possessed. His sweat poured down, his body was covered in mud. He collected the excavation into the pan, filled it with water, and sifted it. That evening the first female lead miner in the world was born (Hirata, 2011: 59).

For Foucault, power is not a direct subjective relationship: the ability of a person/group to impose their will on others (Haryatmoko, 2016: 15). The role of the government in creating jobs certainly does not make the young people of this nation have power over the abilities that they already have. The lack of equal distribution of most citizens is a discourse that is hidden from various power and knowledge relations. Enong's failure to get a job in the city made him forced to go home and think of becoming a tin miner. There was no other choice for Enong, he needed money to buy rice. With all the insults he was shown, he still tried his best to get the lead.

\section{Causes of Poverty}

Poverty is far broader than simply having no money. Poverty is the lack of ability to achieve worthiness in life. More than that, people who are called poor have no hope of changing lives.

\section{a. Individual Causes}

Individual, or pathological, causes that see poverty as a result of the behavior, choices, or abilities of the poor.

When asked for a diploma, he could only answer that he had almost finished elementary school (Hirata, 2011: 38).
The individual caused by Enong himself, that he did not have enough provision to find work was sufficient diploma and expertise. The risk that Enong must accept as a migrant is that he must compete with other prospective workers who come to apply with all his readiness.

"If this child is born," said Syalimah, jokingly, "Our bicycles are no longer enough to piggyback children to the night market." Because these children will be four, whereas they only have rickety bikes (Hirata, 2011: 6).

The number of children or family members causes a person to be unable to meet basic needs. Based on the above quote Zamzami had to save for years to buy a bicycle because his son would become four. It cannot be fulfilled immediately because it is covered by other basic needs such as clothing, food, and shelter.

Shalimah initially refused. It was hard for him to release Enong from school and have to work away from home. The child is an only sixth-grade elementary school. But finally, he was melted because Enong said he could not accept if his younger siblings had to quit school because of costs. He was willing to sacrifice his school (Hirata, 2011: 30).

Zamzami who works as a tin miner is not infrequently only get a little money from the work for days. One need is met causing other needs not met. The problem grew when Zamzami died in mining. His eldest son, Enong, could not help replacing Zamzami as the backbone of the family. Syalimah, Zamzami's wife did not move because he did not have any expertise in working.

\section{b. Low Education Level}

With the lack of skills, knowledge, and more insight, people will not be able to improve their lives for the better. Because with education the community can understand and comprehend how to produce something useful for human life. By learning, people who originally could not be able to, wrong become right, etc. So with a low level of education, the community will be close to poverty.

Kampungku is a mining village with a population of six thousand people. There, no place could be offered to any scholar, as long as he held fast to the dignity of his scholarship. If you just want to be a porter on the Manggar dock, you can carry fish from fishing boats to the plat stand. However, one does not need to collect SKS for the sake of one seed to work to dedicate oneself to the masters at the marketplace plate (Hirata, 2011: 177).

The novel excerpt above illustrates the image of power relations between the government and the country's entrepreneurs. A diploma that is a benchmark for getting a job and changing fate is meaningless in Enong village. Haryatmoko (2016: 15) mentions, power means mute war, which places the conflict in various social institutions, in economic 
inequality, in language, and even in our respective bodies. The absence of efforts made by the government as the holder of power in this country, makes the capitalists continue to silence and oppress the workers without regard to the business they have done. There are no job opportunities for graduates in Enong village, those with high or low education have the same job opportunities. A change in attitude and mentality of the poor is needed to strive to escape poverty. This is done so that poverty is not always passed down from generation to generation.

Run, can you imagine, my son wants to be a teacher of a language from the West? "Sirun was amazed. "We, Run, even Indonesian is not fluent." "Languages from the West? It's not playing, bang, it's not playing (Hirata, 2011: 12).

The poverty experienced by Zamzami's family illustrates that there are still so many people who are practically inadequate in this country, maritime land and plantations that are so much managed by foreign citizens who may have power relations with the Indonesian government.

Enong knows that some of the neighbors' daughters of tin miners have gone to Tanjong Pandan to work as shopkeepers, washers in rich people's homes, or factory workers. He tried to convince his mother that he could work like that. What's so hard about keeping a shop? He said (Hirata, 2011: 30).

Because the lure of working in the city makes life better, Enong follows in the footsteps of girls in her village who migrate to Tanjong Pandan to find work. Continual poverty experienced by someone makes him keep trying to get out of poverty. Many factors cause poverty to decrease to children, grandchildren, and great-grandchildren, including parental employment status, family structure, and the environment. A supportive environment is also a cause of hereditary poverty in the Belitung Malay community.

\section{c. Unemployment}

The number of unemployed in Indonesia is increasing, by creating jobs, the increasing number of unemployed can be overcome because unemployment is one of the biggest causes of poverty in Indonesia.

Suddenly losing the pillar, the family of Syalimah immediately swayed. No expertise and no other family can be asked for help-because all are poor-making the family dies of lice (Hirata, 2011: 29).

Shalimah who needs help after being left by her husband cannot ask his neighbors because all of them are poor. Poverty is hereditary is the same as natural poverty which is caused by natural limitations such as the poor condition of natural resources and environment. This shows that there is the powerlessness of the poor in their roles, and opportunities to get opportunities to obtain resources, which results in patterns of dependency, patterns of weakness, and exploitation of the poor. This habit causes poor conditions to be faced by a community, which is caused by cultural factors. A culture that is alive, believed and developed in society causes the process of preserving poverty in the community itself.

Enong is getting more and more confused because, let alone in the village, in Tanjong Pandan which has many vacancies, he is unable to get a job (Hirata, 2011: 58).

The limited choice of jobs in the village made Enong migrate to the city, unfortunately in the city, he was rejected by the skipper because he was deemed unable to work. Job problems are a serious problem that must be overcome by the government. The lack of government attention is not only on the expansion of employment but also the provision of expertise to the community.

Krupuk factory, excess employees. Grass jelly factory, lack of orders so no need for employees. Grated coconut business, reject it. Boiled noodle restaurant, reject it. Boiled noodle stalls, moreover. Syah Bandar Office, refused because he needed a bachelor's. The regent's office — being ordered to work - for example, a coffee maker or buying cigarettes for the regents' aides - refuse it, because there are already scholars who do that (Hirata, 2011: 38).

The lack of government attention in expanding employment has been the reason Enong did not get a job in Tanjong Pandan. The government is inconsistent in the leveling program of community welfare to encourage optimal growth. The lack of employment makes the percentage of unemployment increase. If the plan to expand employment is only a discourse, unemployment and lack of government attention are the main causes of increasing poverty.

Traditional tin miners always retire early like the director of BUMN. Not because they have spent most of their money, are tired of meetings, or are being forced by the government, but because their bodies are worn out before they get old. Arthritis, an outbreak of elephant disease, a strange skin disease due to the mud virus, a lung that is destroyed because it is always withstanding the cold by constantly smoking, and because of the poor, purchased cigarettes are very cheap cigarettes that are abysmally originated, then seized currents, overwritten by landslides, smoked by live sand, struck by lightning, wrapped in snakes or swallowed by crocodiles, are tragic forms of the end of their short and regal careers (Hirata, 2011: 60).

The profession as a tin panner needs the most attention. Lack of government health services causes many diseases to appear. Poverty causes vulnerability to health, the environment affects the ability of people to escape the shackles of poverty they suffer. The big problem regarding health focuses on the unpreparedness of a city in facilitating the needs of the community. The health of Belitung Malay people 
is very vulnerable because they live in a mining area. Security equipment in the work environment must also support the safety of the workers because they are workers in hazardous areas.

\section{Poverty Solution}

In this case, the government must play an important role in the welfare of society to achieve its desires. Besides, the government must provide various facilities for the community at large.

\section{a. Education}

Improve public education by building school facilities, as well as making education affordable for all Indonesians.

Ms. Nizam is a senior teacher. He is from the Siantar embankment. Decades ago he was appointed by the government to teach in our village. He was highly respected for his courage to wander so far away at a very young age, for the sake of education. $\mathrm{He}$ was the first English teacher in our village (Hirata, 2011: 11).

Bringing teachers to remote villages to overcome the minimal number of teachers in the village. Education is a pioneer in the future development of a nation. For the role of the education sector to play a role in development, especially in poverty alleviation it is necessary to agree on appropriate policies and targets. Belitung, which is the biggest producer of tin, needs local sons to process natural resources. In fact, in that region, education was very low because many poor people were unable to pay school fees. Therefore, efforts to reduce poverty comprehensively and sustainably that give high attention to the field of education are expected to create good resources.

When asked for a diploma, he could only answer that he had almost graduated from elementary school (Hirata, 2011: 8).

The limited expertise and ability of the poor occur due to the lack of government support in providing expertise so that the poor can work and earn a decent income. Three data were found from all data concerning the causes of poverty due to limited expertise. The centralization of all activities in urban areas, including the work of leaving the Belitung Malay people behind. Of course, this makes the lack of human resources in the countryside. This was experienced by Enong when looking for work in the city, not having a diploma and expertise as a reason for the factory officials to reject him.

Ms. Nizam is a senior teacher. He is from the Siantar embankment. Decades ago he was placed by the government to teach in our village. He was highly respected for his courage to wander so far away at a very young age, for the sake of education. He was the first English teacher in our village (Hirata, 2011: 11).

The party that is the cause of this poverty is the government. Governments that have power and policies tend to leave people in poor conditions. They will have difficulty getting access to improve education and skills to improve quality. The poverty that arises, in this case, is due to the inability of the authorities to provide facilities to the people so that in terms of education the teaching staff is considered lacking so that there is no improvement over time.

However, the location of the mine is a land of struggle that is not infrequent to cause a scene, even bloodshed. This is a sensitive matter. If farmers depend on what is planted, miners depend on the land held (Hirata, 2011: 72).

Conflict with the main causes of competition, monopoly, trade, smuggling of mining products has continued from the past until now. The quote above tells the story of Enong who is looking for lead in a new land because other lands are controlled by people. Although tin miners are directly related to the economy, seeing the case depicted in the novel Padang Bulan makes political and environmental nuances take part as well as in the economic movement of the Belitung Malay people, the majority of whom work as miners.

\section{b. Providing land for the people}

There are still many Indonesian people who depend on agriculture. Given that Indonesia currently lacks food, the distribution of land to farmers is the right way to overcome the scarcity of rice.

The heads of tin were mined with native people with hoes, paned with hands, and with one attitude forced by poverty to be buried alive. Wallowing for weeks often produces only a few rupiahs. (Hirata, 2011: 28).

In feudal society, power is based on land and its results. The mechanism of power takes place in a top-down, ruling and controlled relationship (Haryatmoko, 2016: 12). Land reform to the people means giving land to the people to be cultivated and produce results. Land reform in the Padang Bulan novel which is mostly located in mining means giving land to the Belitung Malay people to mine tin. Many monopolies of foreign companies make the original product does not move when the lah is taken. Poverty in Belitung should not occur considering that the city is the largest producer of tin. Many people's land is taken by the government at the request of the capital owner. The government should divide up land so that there is no very high inequality in land ownership.

Those who are horrified by the threat of hunger and the darkness of the future, control the land frantically. Reconnaissance of tin locations produced has become a dangerous cold war between miners (Hirata, 2011: 72).

Land control by the company makes the Belitung Malay people lack land. They end up looking for new land or work as tin panners. Solutions to overcome poverty with land reform, provide opportunities for communities to open businesses and improve the family economy. If land 
reform is not carried out, land tenure will be carried out by certain persons who are reconnaissance of tin land.

The best in that runs on shallow, easily mined surfaces has been plundered by the Netherlands for hundreds of years. The remaining tin which is still good, but deeper, has also been captured by tin airline dredges for decades (Hirata, 2011: 27).

Conflict of interest over access and management of natural resources in the form of tin mining continues. Based on the quote above, historically the tin mining conflict has very long roots, which began in the Dutch era. The presence of illegal miners who have no ties to mining companies creates social conflicts and unfair business competition. The limited land and limited tin resources eventually led Enong to search for new land.

\section{c. Meeting the Import Needs}

To protect domestic industries, it is necessary to have product accuracy that can be developed domestically so that it does not depend on imports while at the same time creating jobs.

At the far end, on the banks of the north Linggang river, Enong and several other miners were panning for tin. They do not mine but scavenge tin which was scattered from heavy equipment and tin sacks that leaked when the tin was loaded onto a barge to be brought to PT Peleburan Timah in Mentok, Bangka (Hirata, 2011: 269).

The government, in this case, must take over control or nationalize the mining industry because it is detrimental to the national interest and prioritizes the people's welfare. If the government succeeds in nationalizing foreign mines, the profits from the sale of mining commodities for the welfare of the people, such as providing free education and health. Many Belitung Malay people, as told in the Padang Bulan novel, mostly work as free tin panners. They scavenge the tin that is scattered from transport trucks and then sold to collectors. The solution to overcome poverty by nationalizing foreign mines and being processed by the state is expected to be able to prosper the people in the country.

When the airline Timah was still victorious, there were dozens of them. They surrounded the village, roaring day and night, digging into the earth to scoop up the tin. Now, the only thing left, where I dream of this fate, is sitting like fossilized dinosaurs (Hirata, 2011: 22).

The quote proves that dozens of tin airlines dredge all tin without residue so that small laborers become excluded because they do not have land. They are only employed as casual laborers and do not participate in policymaking. This control causes losses and results in poverty for the Belitung Malays because they cannot participate in the growth of tin companies.

\section{d. Provide employment}

The number of unemployed in Indonesia is increasing, by creating jobs, the increasing number of unemployed can be overcome because unemployment is one of the biggest causes of poverty in Indonesia.

Since seeing the dictionary and remembering her daughter's wishes, buying a dictionary has become Zamzami's dream day after day. He worked harder in the mining fields and mined by selling roomie juice every time there was a Malay orchestra performance. On Saturday he went out to sea to look for clams to sell at the fish market. On Sunday he sells sugar cane which is stabbed with a stick (Hirata, 2011: 13).

Opening job opportunities as much as possible can reduce the number of unemployed and improve welfare. Zamzami's hard work is a solution to get out of poverty. The plan to expand employment opportunities must also involve the government so that the policy can be carried out properly.

After meeting his friend, that same day Enong went back and forth in the market to offer himself to do anything (Hirata, 2011: 38).

A person's efforts to overcome poverty will not produce results if there is no opportunity. There are fewer opportunities to work because of the imbalance of opportunities and human resources.

After the dawn prayer, she wrapped her hijab tightly, packed hoes, plates and bicycles, kissed her mother's hands, held her siblings for a while, then glided happily while whistling national songs to the lake bantarab. Sometimes he tweeted Englishlanguage children's songs that Mrs. Nizam had taught him before: If you're happy and you know it, clap your hands. She is the first female panning in the history of tin mining. Age no more than 14 years (Hirata, 2011: 61).

Limited job opportunities make someone who does not have the expertise to work as-is. This was experienced by Enong, a little girl who chose to work as a tin panner because she was rejected by several masters. One of the main problems facing the nation and the state of Indonesia is unemployment. High unemployment has a direct impact on poverty. By creating jobs, the government implements a consistent policy to achieve maximum results. This can be done with counseling, coaching and job training.

\section{CONCLUSION}

The results of this study show some conclusions reached in reviewing the Padang Bulan novel by Andrea Hirata according to the description of the life of the Belitung Malay people, among others, a picture of poverty in terms of social life, causes of poverty and, solutions to overcome the problem of poverty. 
The description of poverty contained in the Padang Bulan novel wants to open readers' insights about social life that is still clearly felt by most Indonesian citizens. The poverty picture consists of four figures; Seedy, despicable, tattered and filthy. Not fulfilling the primary needs of almost all poor families. Lack of health services and lack of education services are factors that cause poverty can not be overcome. Poverty is described through social exclusion. It is undeniable that social inequality is often experienced by poor people. Also visible are the various power and knowledge relations that the government and the capitalists have built together with the government's lack of attention to the working class (wages that are not appropriate to the type of work, lack of health benefits for mining workers who are obliged to accept it, rising rates of burial without age restrictions), the demands of the owner of the mine factory that is not following the situation (forcing the hunters to work indefinitely, the lack of adequate facilities to support the good work.

The causes of poverty in the Padang Bulan novel include individual causes, unemployment, low levels of education. Poverty is experienced by many people who have limited expertise, so they cannot work properly to meet their needs. Limited expertise is also due to the lack of public education. As a tinproducing city, the mastery of tin land by certain parties can reduce the work area of the residents. The causes of poverty experienced by the Belitung Malay people in the Padang Bulan novel want to tell and open readers' insights about the conditions experienced by workers in Indonesia. By deconstructing all kinds of discourse circulating in the community and dismantling all kinds of power relations built by the government and entrepreneurs long before that.

The solution to overcome the problem of poverty in the Padang Bulan novel certainly wants to answer all the images and causes of poverty. The government as the highest authority holder of the country must pay attention to the following matters; (1) creating jobs in every corner of the country especially in marginalized areas to answer all social problems faced by the community. (2) Expanding and improving education, like land to gain expertise for employment that is ready to receive skilled workers. (3) land reform for the people, and analysis of foreign mines.

\section{REFERENCES}

Barker, Chris. 2014. Dictionary of Cultural Studies. Yogyakarta: Canisius Publishers.

Endraswara, Suwardi. 2013. Literature Research Methodology. Yogyakarta: CAPS (Center for Academic Publishing Service).

Haryatmoko. 2016. Dismantling the Certainty Regime. Yogyakarta: PT Kanisius.
Hirata, Andrea. 2011. Padang Bulan. Jakarta: Pustaka Fortress.

George, M.W. (2008). The Elements of Library Research: What Every Student Needs now. Princeton: Princeton UniversityPress.

Tripoli, Faruk. 2010. Introduction to the Sociology of Literature. Yogyakarta: Student Library.

Ratna, INyoman Kutha. 2007. Theories, Methods, and Techniques: Literary Research. Yogyakarta: Student Library.

Suharto, Eddie. 2009. Poverty and Social Protection in Indonesia. Jakarta: Alfabeta.

Soekanto, Soerjono. 1982. Sociology. Jakarta: PT Rajagrafindo Persada

Wahyuningtyas, Sri and Wijaya Heru Santosa. 2011. Literature: Theory and Implementation. Surakarta: Yuma Reader.

Wellek and Weren. 2014. Literary Theory. Jakarta: Kompas Gramedia. 